Primljen / Received: 7.2.2012.

Ispravljen / Corrected: 7.8.2012.

Prihvaćen / Accepted: 25.9.2012.

Dostupno online / Available online: 15.10.2012.

\section{Impact of shallow earthquakes on the Sehzade Mehmet Mosque}

\section{Authors:}

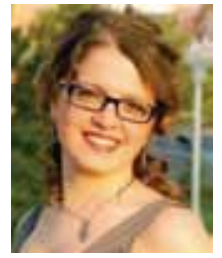

Zeynep Yeșim Ilerisoy, M.Sc.

Gazi University in Ankara, Turkey

Department of Architecture

zyharmankaya@gazi.edu.tr

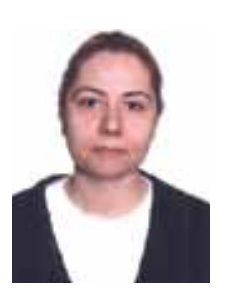

Asena Soyluk, Ph.D.

Gazi University in Ankara, Turkey

Department of Architecture

asenad@gazi.edu.tr

\section{Zeynep Yeșim ilerisoy, Asena Soyluk}

\section{Impact of shallow earthquakes on the Sehzade Mehmet Mosque}

Earthquakes have negative impact on both the existing structures and buildings of historic significance. This study demonstrates destructive impact of shallow earthquakes (over 7 in magnitude) on historic structures. In addition, the study analyses the earthquake impact on the Sehzade Mehmet Mosque in Istanbul. The mosque model is made by applying the structural analysis program, SAP2000, which uses the finite element method. The effects of these earthquakes on the bearing frame of the mosque are analysed. The results obtained show that, due to difference in magnitudes of the two earthquakes, shallow earthquakes cause major damage to historic structures.

\author{
Key words: \\ earthquake, dynamic analysis, time-history analysis, magnitude, mosque
}

Stručni rad

Zeynep Yeşim Ilerisoy, Asena Soyluk

\section{Utjecaj plitkih potresa na džamiju Sehzade Mehmet}

Potresi negativno djeluju kako na postojeće gradevine tako i na građevine od povijesnog značenja. U radu se razmatraju destruktivni utjecaji plitkih potresa, magnitude veće od 7, na povijesne građevine. Analizira se utjecaj potresa na džamiju Sehzade Mehmet u Istanbulu. Džamija je modelirana primjenom programa za analizu konstrukcija SAP2000 metodom konačnih elemenata. Razmatran je utjecaj navedenih potresa na nosivi okvir džamije. Dobiveni rezultati pokazuju da uslijed razlike u magnitudama dvaju potresa, plitki potresi dovode do velikih oštećenja povijesnih građevina.

Ključne riječi:

potres, dinamički proračun, odziv u vremenu, magnituda, džamija

Fachbericht

Zeynep Yeşim Ilerisoy, Asena Soyluk

\section{Einfluss von schwachen Erdbeben auf die Schehzade Mehmet Moschee}

Erdbeben haben einen negativen Einfluss auf bestehende sowie historische Bauten. In der Arbeit werden destruktive Einflüsse von schwachen Erdbeben einer Magnitude von über 7 auf historische Bauten betrachtet. Es wird der Einfluss von Erdbeben auf die Schehzade Mehmet Moschee in Istanbul analysiert. Die Moschee wurde unter Anwendung des Konstruktionsanalyseprogramms SAP2000 modelliert. Es wurde der Einfluss der angeführten Erdbeben auf den Tragrahmen der Moschee gemessen. Die erhaltenen Resultate zeigen auf, dass infolge der Magnitudendifferenz der beiden Erdbeben schwache Erdbeben zu großen Beschädigungen von historischen Bauten führen. 


\section{Introduction}

Historical structures are the treasures left behind from the thousands of year's cultural richness. They are world's cultural heritage and have to be protected. They give us insights into the sociological, economic, political and religious tenets our ancestors lived by. A correct evaluation of these implications enables us to interpret our present and plan our future.

Historic masonry structures have low ductility and due to their stiff and brittle structural components, they are usually severely damaged during strong earthquakes. The main reason for damage is the lack of the ductility that prevents a structure being able to sustain the displacements and distortions caused by severe earthquakes. Damaged caused by earthquakes to historic buildings can be very destructive [1]. In determining the structural capacity of historical buildings, various criteria should be considered. However the lack of insight and models for the complex behaviour of units, mortar, joints and masonry as a composite material has made the analysis of masonry rather difficult. Sehzade Mehmet Mosque which was constructed by Mimar Koca Sinan, the "Great Architect Sinan", in his apprenticeship term at a risky earthquake region, Istanbul, has been selected as case study.

\section{Earthquakes}

Turkey experienced two major earthquakes in 1999, which occurred 86 days apart on the North Anatolian Fault system. Two sequent earthquakes with magnitudes over 7 in the same region are very seldom in the world seismic history. The North Anatolian Fault (NAF) with a length of $1500 \mathrm{~km}$ is one of the most active and largest strike-slip faults in the world, which causes destructive earthquakes by slipping at an average rate of 20-25 mm/year. NAF is the most active component in the tectonic evolution of Anatolia. Within this century more than 25 earthquakes have occurred along the fault ruptured over $900 \mathrm{~km}$ of its length [2]. This earthquake sequence is illustrated in Figure 1 with the dates of the events and extends of rupture they created. As inferred from this figure, occurrence of large magnitude earthquakes close to cities in Turkey is inevitable due to high seismic-rate of the NAF, and its crossing to the most densely populated environments.

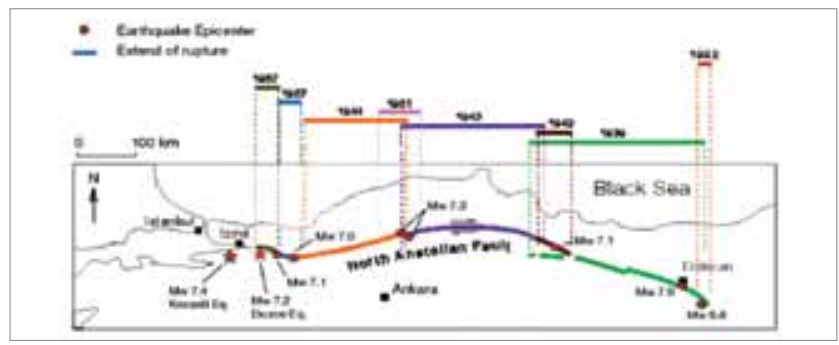

Figure 1. Earthquakes along the North Anatolian Fault in this century [3]

The August 17, 1999 Kocaeli earthquake occurred at 03:02 a.m. (Local Time), which ruptured about $140 \mathrm{~km}$ of the surface
(Figure 2). The epicentre was Golcuk at the eastern end of Marmara Sea, Longitude 29.91 E and Latitude 40.70 N. [4] The Earthquake Research Department (ERD) of Turkey declared the magnitude to be Mw: 7.51 and the depth was about 10 $\mathrm{km}$. The measured peak acceleration was $0.18 \mathrm{~g}$.

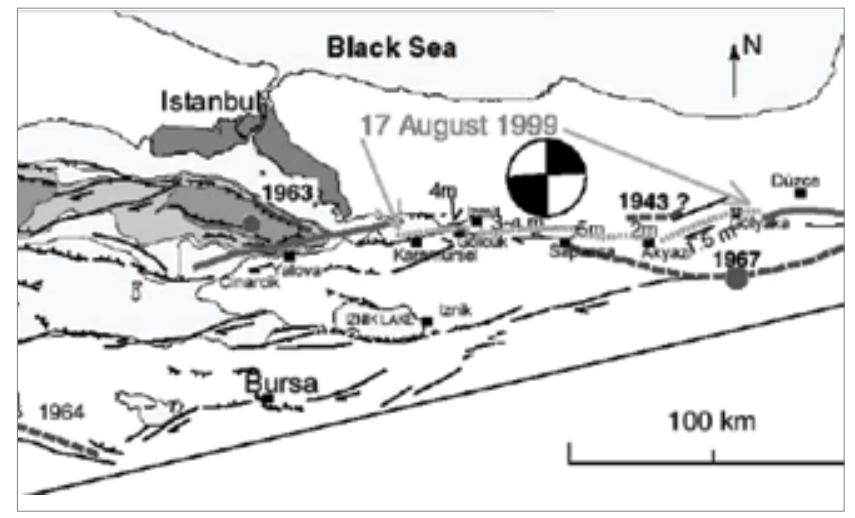

Figure 2. August 17, 1999 Kocaeli earthquake [5]

Three months after the 17 August event (12 November 1999), Mw 7.14 Düzce earthquake ruptured another $40 \mathrm{~km}$ segment of the same fault which was broken during the Kocaeli earthquake, toward further east. The second rupture zone started from the termination of the 17 August rupture. A bi-lateral, symmetrical, predominantly strike-slip rupture occurred, with the epicentre located at $40.76 \mathrm{~N}$ and $31.15 \mathrm{E}$, and the focal depth at $11 \mathrm{~km}$. The measured peak acceleration was $0.029 \mathrm{~g}[6]$.

\subsection{Earthquake magnitude}

Earthquake magnitude is a measure of the amount of energy released during an earthquake. Depending on the size, nature and location of an earthquake, seismologists use different methods to estimate magnitude. The most commonly used method is that devised by and named after Richter. Richter magnitude $M$ or $M_{L}$ is computed from the surface-wave portion of seismograms. It is an indirect measure of the energy released. It is defined as

$M_{L}=\log A-\log A_{0}$

where $A$ is the maximum recorded trace amplitude for a given earthquake at a given distance as written by Wood-Anderson instrument and $A_{0}$ is that for a particular earthquake selected as standard. The other methods to estimate magnitude are surface wave magnitude $\left(M_{S}\right)$, body wave magnitude $\left(m_{B}\right)$, duration magnitude $\left(\mathrm{M}_{\mathrm{D}}\right)$ [7]. Recently, the moment magnitude scale (abbreviated as MMS; denoted as $\mathrm{M}_{w}$ ) is developed by seismologists to measure the size of earthquakes in terms of the energy released. The MMS is now the scale used to estimate magnitudes for all modern large earthquakes by the United States Geological Survey. 
Moment magnitude is calculated using moment released during an earthquake rupture. The symbol for the moment magnitude scale is $M_{w}$, with the subscript $w$ meaning mechanical work accomplished. The moment magnitude $M_{w}$ is a dimensionless number defined by:

$M_{w}=\frac{\log M_{0}}{1,5}-10,7$

where $M_{0}$ is the magnitude of the seismic moment in dyne centimetre $\left(10^{-7} \mathrm{Nm}\right) . \mathrm{M}_{0}$ can be estimated from the recorded wave spectra [9].

\section{Method of analysis}

Sehzade Mehmet Mosque was built between 1543 and 1548 by Sinan to commemorate the memory of one of Süleyman's sons, the crown prince Mehmet (Figure 3a). The mosque, which was built according to the masonry technique using limestone, has a square plan, covered by a central dome, buttressed on four sides by semi-domes (Figure 3b).

The central dome is supported by four arches resting on four piers, and has a diameter of 19 meters and it is 37 meters high. Based on a square plan, the Sehzade Mehmet Mosque measures $38 \mathrm{~m}$ x $38 \mathrm{~m}$ in area and has a front courtyard. This hierarchical superstructure sits on walls that are fortified by five buttresses each. The drum has 24 windows [10]. The structural elements of the Sehzade Mehmet Mosque are composed of domes, transition elements (elements used to pass from circular geometry to the polygon one; pendantives), arches, counter weight towers, piers, walls, buttresses and foundations [11].

The numerical model used for Sehzade Mehmet Mosque is created by SAP 2000 finite element program. The size and complexity of the structure created a model consisting of 7468 joints, 2976 shell elements and 2352 solid elements (Figure 4). While modelling the Sehzade Mehmet Mosque, solid elements are used for arches and walls, and shell elements for pendantives and domes. In Table 1, the material properties of the Sehzade Mehmet Mosque were taken from the studies done at the Hagia Sophia and Suleymaniye mosques [12].

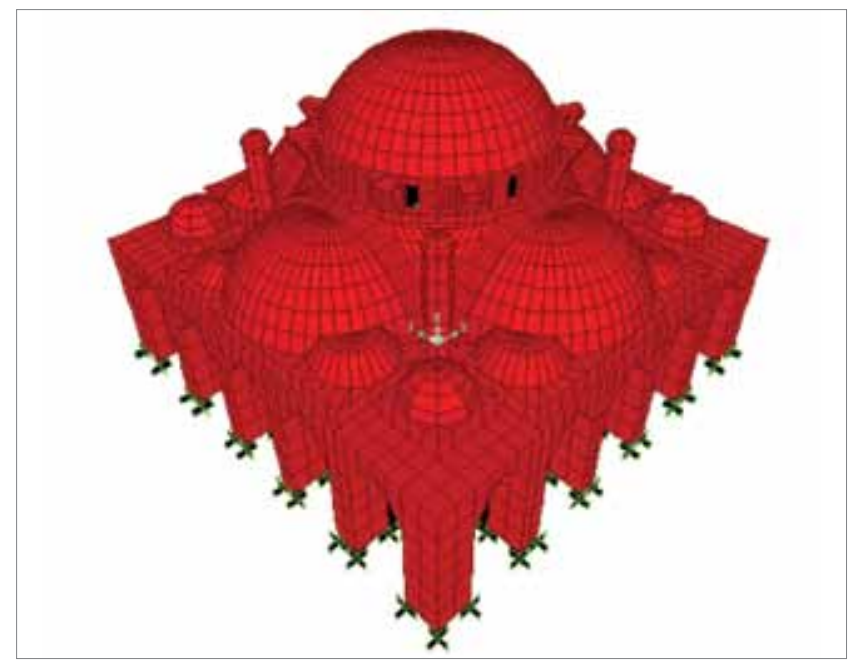

Figure 4ure Finite element model of Sehzade Mehmet Mosque

Table 1. Material properties [12]

\begin{tabular}{|c|c|c|c|c|c|}
\hline $\begin{array}{c}\text { Type } \\
\text { of element }\end{array}$ & $\begin{array}{c}\text { Characteristic } \\
\text { of element }\end{array}$ & $\begin{array}{c}\mathrm{E} \\
{\left[\mathrm{kN} / \mathrm{m}^{2}\right]}\end{array}$ & $\begin{array}{c}\gamma \\
{\left[\mathrm{kN} / \mathrm{m}^{3}\right]}\end{array}$ & $\begin{array}{c}\text { Poisson } \\
\text { Ratio } \\
{[\mathrm{U}]}\end{array}$ & $\begin{array}{c}\text { Thickness } \\
{[\mathrm{m}]}\end{array}$ \\
\hline Arches & Solid & $850 \mathrm{E}+4$ & 21,9 & 0,20 & \\
\hline Piers & Solid & $850 \mathrm{E}+4$ & 21,9 & 0,18 & \\
\hline Main Dome & Shell & $300 \mathrm{E}+4$ & 20,0 & 0,18 & 0,5 \\
\hline Pendantives & Shell & $300 \mathrm{E}+4$ & 20,0 & 0,20 & 0,7 \\
\hline Semi-domes & Shell & $300 \mathrm{E}+4$ & 20,0 & 0,18 & 0,7 \\
\hline
\end{tabular}

In addition to the structural characteristics (materials, construction types, etc.) that affect the structural behaviour during an earthquake, local soil conditions also plan important roles in the damage level depending on the dynamic characteristics of the earthquake and soil. For the dynamic analyses of the Sehzade Mehmet Mosque, the time history method is preferred. In our study, Kocaeli and Duzce earthquakes located on the North Anatolian Fault Zone which is right-lateralfault is considered to eliminate the fact that the earthquake
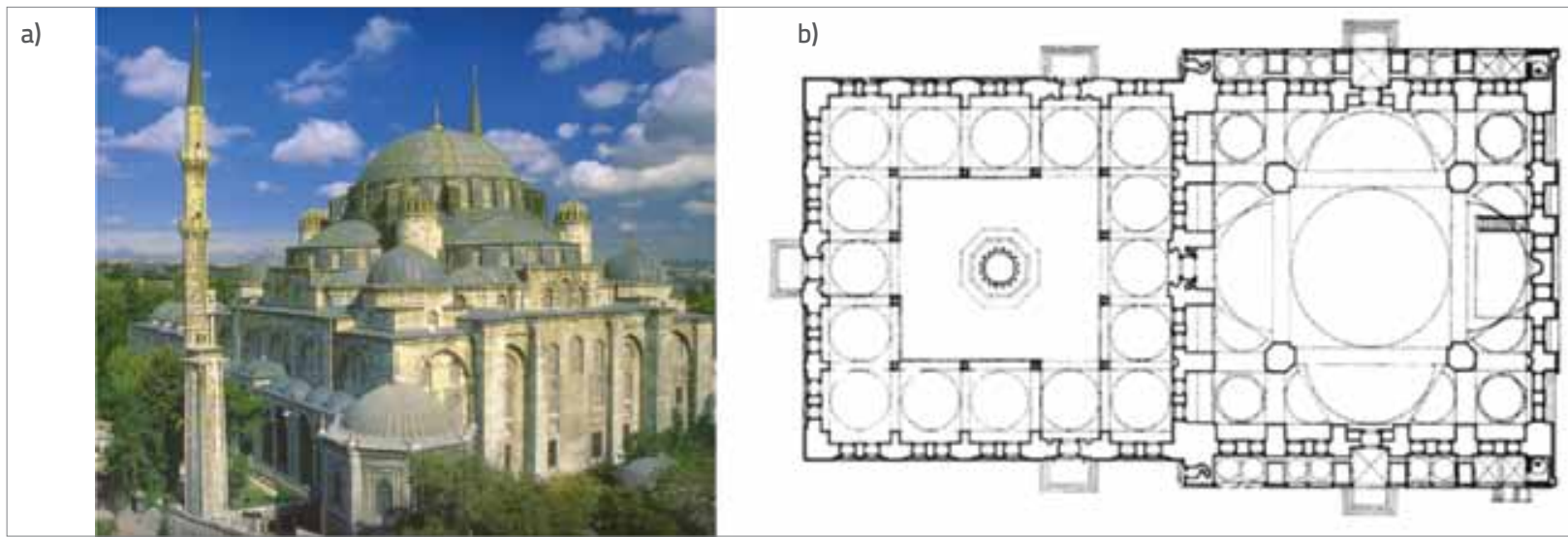

Figure 3. General view of Sehzade Mehmet Mosque, Plan view of Sehzade Mehmet Mosque 
Table 2. Recorded peak ground accelerations of Fatih Station Duzce and Kocaeli

\begin{tabular}{|c|c|c|c|c|c|c|}
\hline Earthquakes & $\begin{array}{c}\text { Distance from } \\
\text { rupture }[\mathrm{km}]\end{array}$ & $\begin{array}{c}\text { Earthquake depth } \\
{[\mathrm{km}]}\end{array}$ & Site Class & \multicolumn{3}{|c|}{ Peak acceleration (g) } \\
\cline { 5 - 7 } & 168 & 11 & Soft Soil & 0,029 & 0,024 & 0,01 \\
\hline Duzce & 65 & 10 & Soft Soil & 0,18 & 0,16 & 0,13 \\
\hline
\end{tabular}

a)

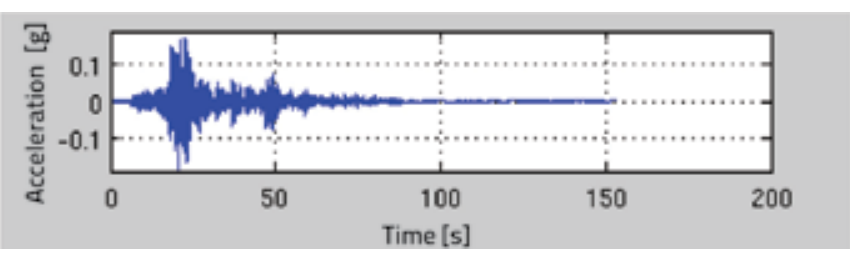

b)

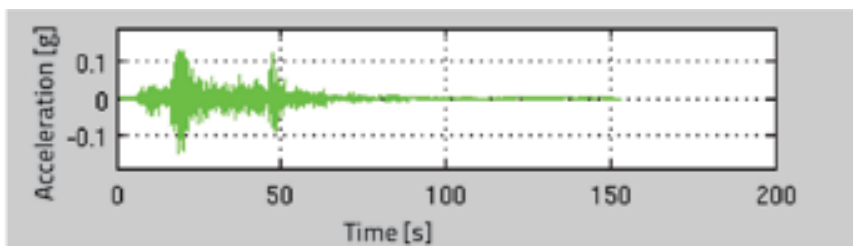

Figure 5. Fatih station recordings during the Kocaeli earthquake; a) E-W direction; b) N-S direction) [13]

a)

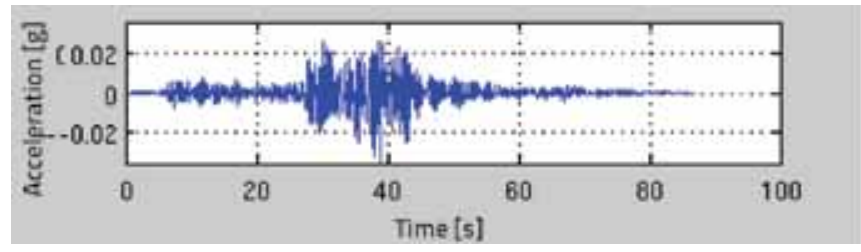

b)

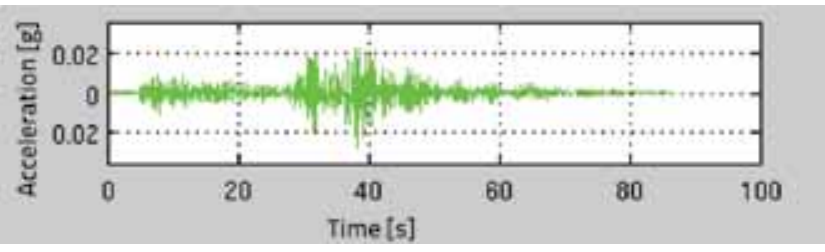

Figure 6. Fatih station recordings during the Duzce earthquake; a) E-W direction; b) N-S direction [13]

waves dissipate depending on the distance from the focus zone. Also, the data given in Table 2 are obtained from the same earthquake recording station (Fatih, Istanbul) to satisfy that the earthquake waves are not affected by the properties of the geologic units through which they pass while propagating from the focus zone. In Figure 5 and 6, Duzce and Kocaeli earthquake ground motions' recordings are shown.

Mathematically, an earthquake of specific magnitude results in seismic waves with amplitudes proportional to $10^{x}$. The actual seismic-wave amplitude at a particular site depends on the distance of the site from the earthquake epicentre, the depth of the earthquake, and local near-surface conditions. When we compared the seismic shaking produced by a magnitude 7.54 earthquake with the shaking from a magnitude 7.14 earthquake, Eq. 3 is used.

$A_{(M=X)}=K \times 10^{X}$

where $\mathrm{K}$ is an arbitrary constant. From Eq. 3, Duzce earthquake magnitude is approximately $234 \%$ smaller when compared with the magnitude obtained from Kocaeli earthquake.

\section{Periods of the mosque}

The first 5 modes considered in the study are shown in Figures 7 and 8 . As can be observed, while the first two modes correspond to translational motions in the $x$ and $y$ directions, respectively, third mode corresponds to the squeezing mode, fourth mode corresponds to the torsional mode and fifth mode corresponds to the opening mode.
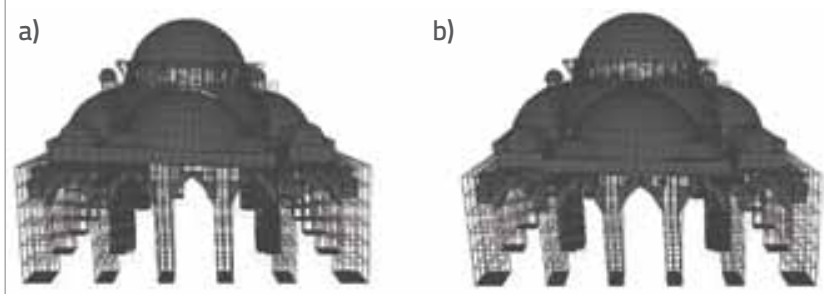

Figure 7. a) Mode 1 ( $T=0.493 \mathrm{~s}, \mathrm{x}$ translation); b) Mode 2 ( $T=0.465 \mathrm{~s}, \mathrm{y}$ translation)

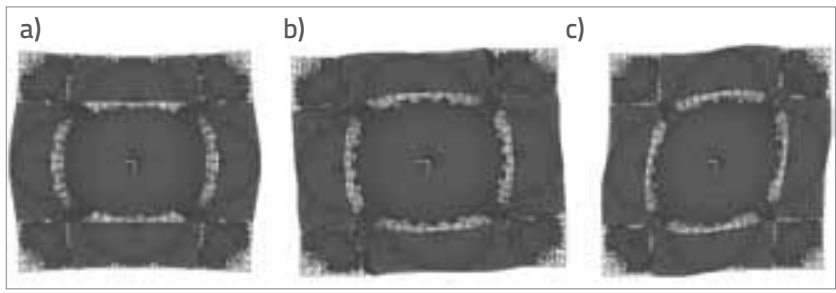

Figure 8. a) Mode 3 ( $T=0.440 \mathrm{~s}$, squeezing); b) Mode 4 ( $T=0.379 \mathrm{~s}$, torsional); c) Mode 5 ( $T=0.314 \mathrm{~s}$, opening)

\section{Comparison of dynamic responses of Sehzade Mehmet Mosque}

The structural deformations of the Sehzade Mehmet Mosque obtained from the dynamic analyses are compared for 
Kocaeli and Duzce earthquake's strong ground motions. The deformed shapes of the mosque determined for Kocaeli and Duzce ground motions are shown in Figures 9 and 10. The relative horizontal displacement values determined from the considered analyses are also shown at the top of the main dome and at the top of a counter weight tower (Figure 9).

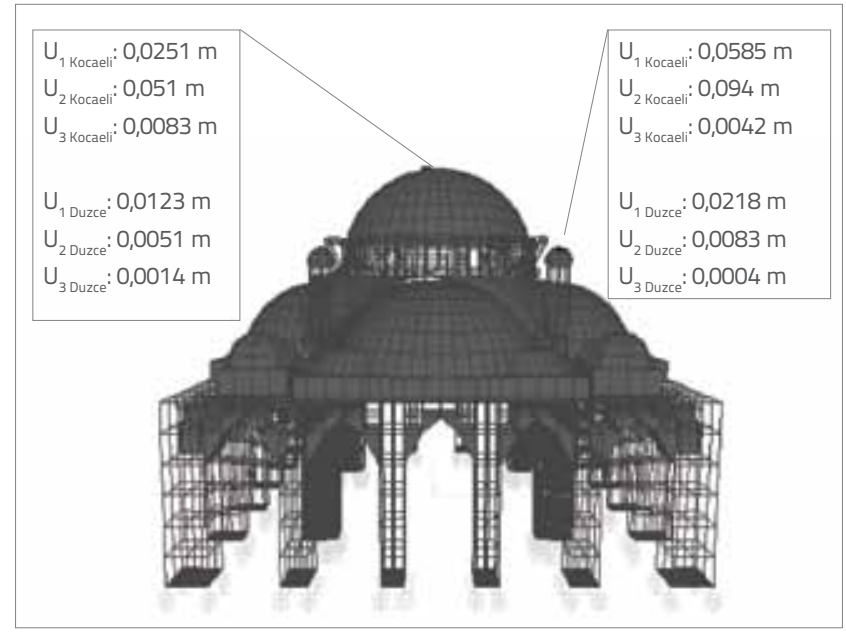

Figure 9. Relative displacements at the top of the main dome of the system and the top of a tower of the system

The relative displacements determined at the top of the main dome are $51 \%, 90 \%$ and $83 \%$ smaller for Duzce earthquake strong ground motion at $\mathrm{U} 1, \mathrm{U} 2$ and $\mathrm{U} 3$ directions, respectively, if compared with Kocaeli strong ground motion. If the displacement at the top of a tower is considered, it can be observed that Duzce earthquake strong ground motion at U1, U2 and U3 directions reduce the displacement 63\%,91\% and $90 \%$, respectively, relative to Kocaeli strong ground motion.

The stresses of the Sehzade Mehmet Mosque obtained from the dynamic analyses are compared for Kocaeli and Duzce earthquakes at significant points (Figure 10). These points; $A, B, C$ accordingly, are selected to observe the stress values obtained from the analysis. Point $A$ is located on the arch which supports the main dome. Point $B$ is located on the counter weight tower. Furthermore Point $C$ is at the joint between the base and the pier.

As it can be seen from the Table 3, S11 stresses occurred at the mosque for Kocaeli earthquake on joints $A, B$ and $C$ are approximately $84 \%, 82 \%$ and $87 \%$ respectively bigger than those of the stresses obtained for Duzce earthquake. Also the S22 stresses occurred at the mosque for Kocaeli earthquake on joints $A, B$ and $C$ are approximately $85 \%, 86 \%$ and $87 \%$ bigger than Duzce earthquake. The evolution of S33 stress values occurred at the mosque for Kocaeli earthquake on joints $A, B$ and $C$ are approximately $84 \%, 88 \%$ and $87 \%$ respectively bigger than those of the stresses obtained for Duzce earthquake.

Table 3. Stress values of Sehzade Mehmet Mosque for Kocaeli and Duzce Earthquakes

\begin{tabular}{|c|c|c|c|c|}
\hline Earthquake & $\begin{array}{c}\text { Position } \\
\text { of stress } \\
\text { observation }\end{array}$ & $\begin{array}{c}\mathrm{S} 11 \\
{\left[\mathrm{kN} / \mathrm{m}^{2}\right]}\end{array}$ & $\begin{array}{c}\mathrm{S} 22 \\
{\left[\mathrm{kN} / \mathrm{m}^{2}\right]}\end{array}$ & $\begin{array}{c}\mathrm{S33} \\
{\left[\mathrm{kN} / \mathrm{m}^{2}\right]}\end{array}$ \\
\hline Kocaeli & A & 3777,16 & 308,41 & 358,00 \\
\hline Duzce & $A$ & 604,97 & 45,33 & 57,20 \\
\hline Kocaeli & B & 4316,15 & 2136,60 & 236,68 \\
\hline Duzce & B & 794,58 & 311,50 & 29,47 \\
\hline Kocaeli & C & 3482,06 & 3916,68 & 19467,91 \\
\hline Duzce & C & 473,96 & 531,03 & 2641,68 \\
\hline
\end{tabular}

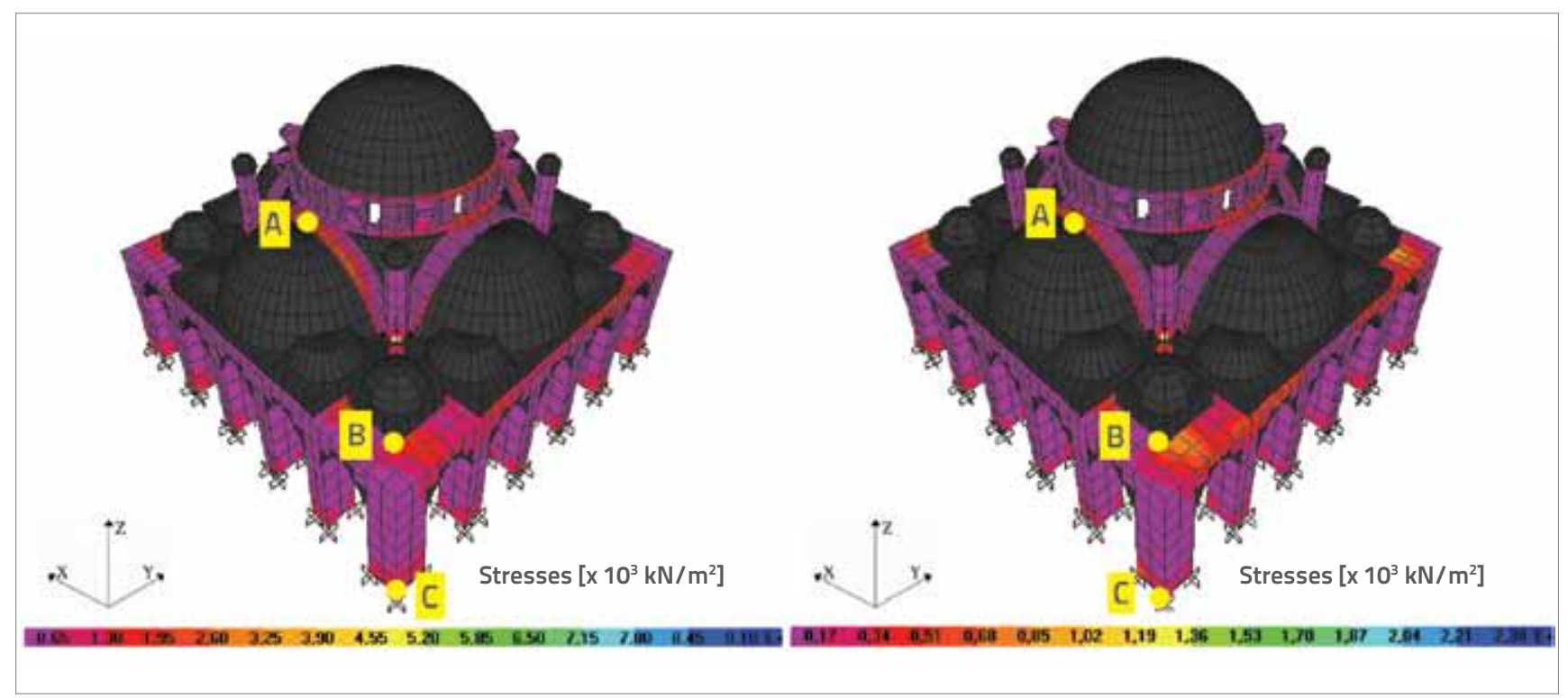

Figure 10. Contour lines of S11 stresses of the system: a) Kocaeli earthquake; b) Duzce earthquake 


\section{Conclusions}

In this paper it is intended to determine the dynamic behaviour of the Sehzade Mehmet Mosque located in Istanbul under different earthquake motions with magnitudes over 7 in the same region. To determine the dynamic behaviour of the mosque, Kocaeli and Duzce strong ground motions are used at $U 1, U 2, U 3$ directions. The structural responses of the Sehzade Mehmet Mosque obtained from the dynamic analyses are compared for these seismic motions.

As the dynamic analyses results of the mosque reveal that structural responses increase substantially for Kocaeli earthquake $\left(M_{w}: 7.51\right)$ when compared with Duzce earthquake

\section{REFERENCES}

[1] Gavrilovic, P., Kelley, S. J., Sendova, V.: A Study of Seismic Protection Techniques for the Byzantine Churches in Macedonia. APT Bulletin, 34 (2), pp. 63-69, 2003.

[2] Barka, A., Nalbant, S.: Modelling of the Marmara Earthquakes after year of 1700 . Proceedings of the 1st meeting of Active Tectonic Research Group (ATAG-1), Istanbul: Istanbul Technical University press, pp. 32-40., 1998.

[3] USC-GEES. University of Southern California, Geotechnical Eq. Engineering Server, CA (http:// geoinfo.usc.edu/gees), 1999.

[4] Toksöz, M.N., Reilinger, R.E., Doll, C.G., Barka, A., Yalçın, N.: Izmit (Turkey) earthquake of 17 August 1999. First report. Seismological Research Letters, 6 (6), pp. 669-679, 1999.

[5] Barka, A.: The August 17 and November 121999 Earthquakes in the Eastern Marmara Sea Region. Proceedings of the International Symposium on the Kocaeli Earthquake, Istanbul, pp. 383-388, 1999.

[6] Anderson, J.G., Sucuoglu, H., Erberik, A., Yilmaz, T., Inan, E., Durukal E., Erdik, M., Anooshehpoor, A., Brune J.N., Ni, S.D.: Strong Ground Motions from the Kocaeli and Düzce, Turkey, Earthquakes and Possible Implications for Seismic Hazard Analysis. Earthquake Spectra, Volume 16, Supplement A, pp.113-137, 2000.
$\left(\mathrm{M}_{\mathrm{w}}\right.$ : 7.14). The structural displacements obtained from the Duzce earthquake ground motion at U1, U2, U3 directions are approximately $57 \%, 90 \%, 85 \%$ respectively, smaller than those obtained from Kocaeli earthquake ground motion. This structural response reduction is important for both understanding the importance of magnitudes and determining the damages of the structural elements caused by these strong ground motions. Also the stresses occurred at the mosque under Kocaeli earthquake is approximately $87 \%$ bigger than the stresses obtained under Duzce earthquake. It can be concluded that the structural responses for masonry mosque type systems might be rather different even if there is a magnitude difference in seismic magnitudes of two shallow earthquakes occurred at the same location and fault.

[7] Kramer, S.L.: Geotechnical Earthquake Engineering, New Jersey: Prentice Hall, pp. 48-49, 1996.

[8] NISEE, Pacific Earthquake Engineering Research Center, University of California, CA (http://nisee.berkeley.edu/turkey/ Fturkch1.pdf), 2011.

[9] Bozorgnia, Y., Bertero, V. V.: Earthquake Engineering Seismology to Performance-Based Engineering, Florida: CRC Press, pp. 1315., 2004

[10] Kuran, A.: The Grand Old Master of Ottoman Architecture, Istanbul: Ada Press Publishers, pp. 64-68, 1987.

[11] SAP2000, Integrated Structural Analysis and Design Software, Computers and Structures, Inc., Berkeley, California, 2005.

[12] Kaya, S.M., Aydinoglu, M.N., Erdik, M., Yuzugullu, O.: Determination of Dynamic Characteristics of Suleymaniye Mosque by Analytical and Experimental Methods. Compatible Materials for the Protection of European Cultural Heritage. Istanbul, pp. 56-68, 1998.

[13] Peer Ground Motion Database, Pacific Earthquake Engineering Research Center, University of California, CA (http://peer. berkeley.edu/peer_ground_motion_database/spectras/1/ unscaled_searches/1537/edit), 2011. 